\title{
Two Cups with Incised Decoration from Kommos, Crete*
}

\author{
MARIA C. SHAW
}

(P1s. 61-62)

\begin{abstract}
Two black-glazed cups with unusual figurative scenes, executed by incision, were found in a temple of eighth-seventh century B.C. date at Kommos, Crete. Possible interpretations of the scenes are considered, but emphasis is placed on an analysis of their motifs in the context of Cretan seventh century art. Incised and repoussé metalwork appears to have been a major source of inspiration, with specific parallels indicating a date in the second half of the seventh century.
\end{abstract}

Like other products of Cretan art which often defy definition, the two cups discussed here, found recently in a temple at Kommos on the south coast of Crete, are unusual both in their native Cretan context and in terms of Greek art. ${ }^{1}$ The cups, labelled here A (the better preserved one; pls. 61, figs. 1-3; 62, figs. 4-5; ill. 1) and B (pl. 62, fig. 6 and ill. 3), were badly broken; the sherds of cup A were scattered in two locations, although most were by a hearth, where sherds of B were also found amid other dedications: small pieces of faience, shells, fossils and pottery. The pottery ranged in date from Subgeometric to Orientalizing, including a Corinthian or Corinthianizing aryballos of the second half of the seventh century B.C., but a few sherds of the sixth to fourth centuries B.C. clearly were deposited after the temple went out of use in the late seventh century. ${ }^{2}$

Cup A (pls. 61, figs. 1-3; 62, 4-5; ill. 1).

Kommos Inv. no. C2396; Herakleion Museum no. II 25787. H.: 0.114 m.; D. rim: 0.121 m.; D. restored base: $0.038 \mathrm{~m} . ; 90 \%$ of profile restored from 34 pieces. Convex body, vertical strap handle and flaring offset rim. Surface covered on both sides with dull, black glaze; incised decoration on exterior only.

On the lip is a crudely executed frieze, composed of two interlocked horizontal guilloche bands with scalloped contours above and below each band. ${ }^{3}$ The frieze was drawn rather unevenly in two separate sections, starting at either side of the handle and meeting

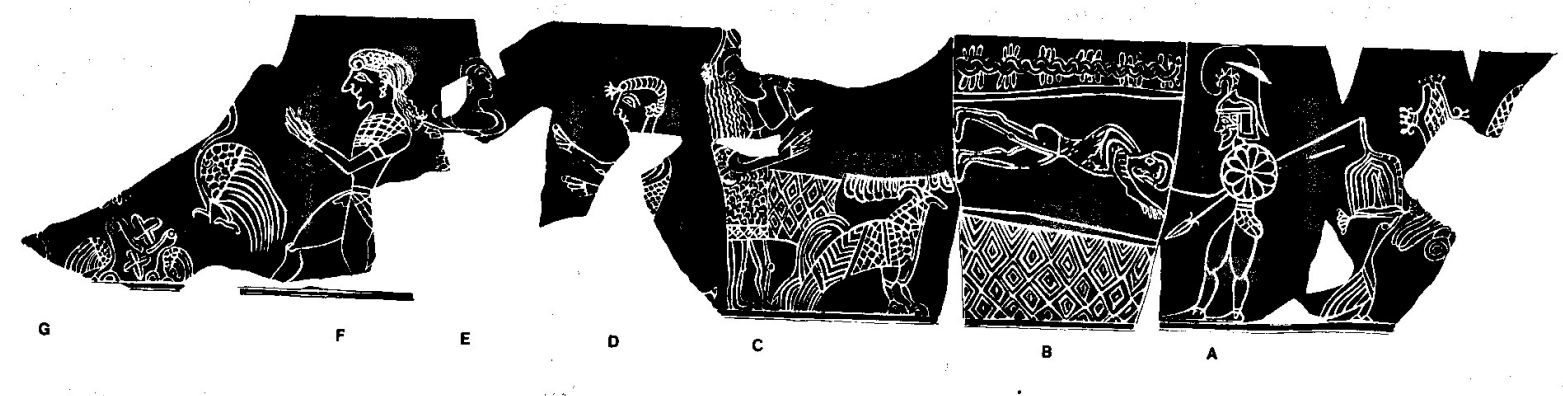

Ill. 1. Kommos, drawing of figurative scene on cup A. (G. Bianco)

* I would like to thank J. Boardman, P. Callaghan and J. Shaw for their valuable ideas and comments on the text.

In addition to the standard abbreviations, I have used the following:

CCO J. Boardman, The Cretan Collection in Oxford (Oxford 1961).

EHP D. Levi, Early Hellenic Pottery in Crete (Amsterdam 1969).

Fortetsa J.K. Brock, Fortetsa (BSA Suppl. Paper 2, Cambridge 1957).
Prinias A. Lembessi, Oi Steles tou Prinia (Athens 1976) (in Greek).

${ }^{1}$ See reports on the excavations at Kommos by J.W. Shaw in Hesperia 49 (1980) 245-48, Hesperia 50 (1981) 232-36, 238, 240-51.

${ }^{2}$ The ceramic context has been defined by P. Callaghan, who is pursuing its study. For a preliminary discussion of the cups, see Hesperia 49 (1980) 231-33 and pl. 63 c, d, and Hesperia 50 (1981) 236, n. 79, 240. The cups were mended and cup A completed in plaster by C. Sease.

${ }^{3}$ Cf. Fortetsa, patterns $11 \mathrm{ak}, 11 \mathrm{am}$ and $11 \mathrm{aq}$. 
at a point off-center marked by two concentric circles enclosing an x (pl. 62, fig. 4). Below the lip is a broad zone containing human figures, birds, plants and abstract ornaments. This zone is separated by double lines from a bottom frieze of petal-like forms, often described as "tongues," which converge toward the base. On the handle, of which only the top and base are preserved, the decoration of the lip and base is repeated, with a guilloche above, here single and on a small scale, and a band of tongues below. The correspondence of patterns suggests that, although the artist was a poor draftsman, he nevertheless gave some thought to compositional matters. All motifs described so far, except the lip band, are outlined with double lines. the only figure in the scene in a horizontal position, first attracts attention. Although he is lying down, he is represented as if he were standing in right profile. Head and feet touch the vertical sides of the frame. Arms are awkwardly rendered, one hanging down, the other bent over an apparently frontal chest. The hands are large. Because the glaze is worn in the area of the face, we can barely make out the summarily incised eye and ear and a simple curving form for the hair. Short diagonal lines over the chest suggest a garment, but whether there was also a kilt is unclear. Oddly, double outlines have been used only for the legs, a peculiarity we shall encounter again.

The frame containing the man is defined by a guilloche band above and a panel below, covered by an

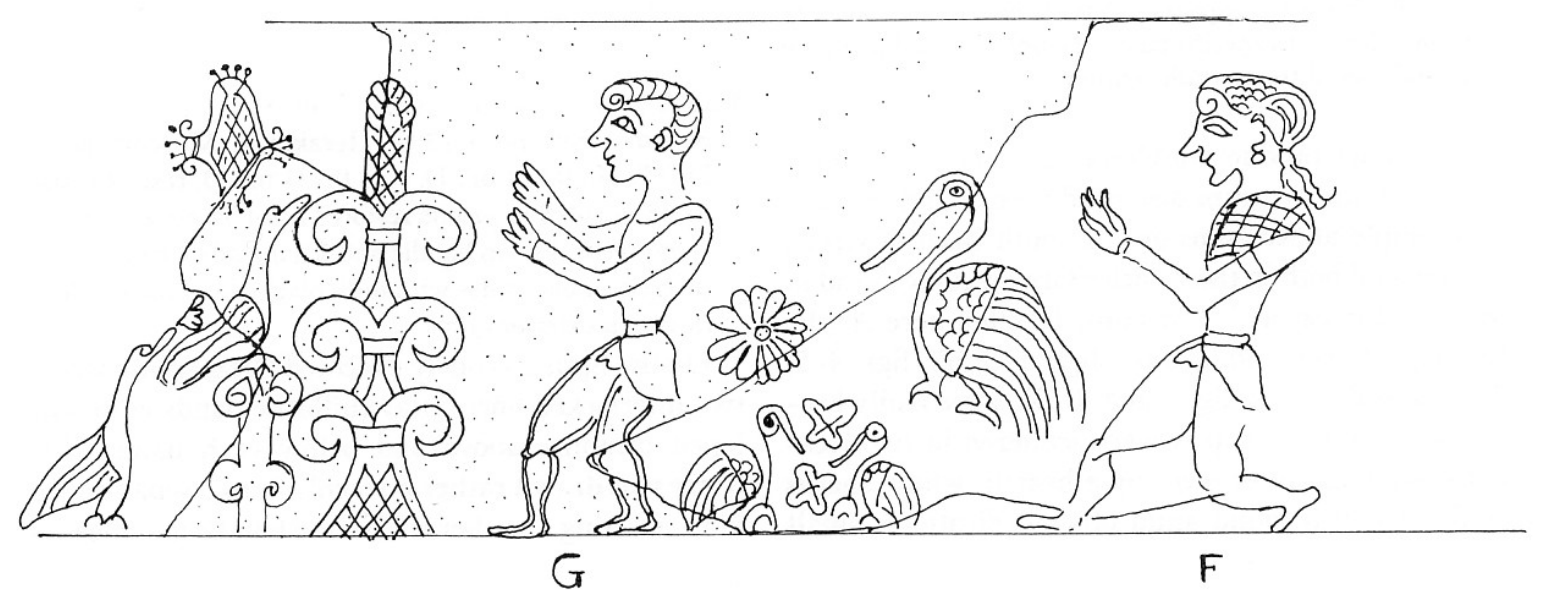

Ill. 2. Kommos, restored drawing of missing part of cup A. (M.C. Shaw)

The decoration of the central zone is elaborate and detailed. The human figures, variously preserved, are labelled here for ease of reference as A-G consecutively, moving from right to left (ill. 1). "Right" and "left" are from the observer's point of view, unless otherwise stated. Seven figures are preserved: a hoplite (A); a prostrate man (B); another standing figure facing right $(\mathrm{C})$; two individuals in left and right profile, respectively ( $\mathrm{D}$ and $\mathrm{E}$ ); a young man running left (F) and, finally, G, known only from part of a leg which is turned to the left. Ill. 1 is a copy of the figured scene as preserved, while ill. 2 gives a possible reconstruction of the most damaged area of the cup (discussed below). Completion of figure $\mathrm{G}$ shows that there is little room for another person beyond the seven preserved.

The prostrate man (B), emphatically framed and elaborate lounge pattern of which the innermost units are marked by short vertical lines. The guilloche itself is adorned with groups of leaves or petals projecting above and below it at regular intervals.

The hoplite (A), stepping toward the prostrate man and clad in a belted, cross-hatched kilt, is better drawn. His features are sharp and his beard marks him as a mature man. His arms are invisible, unless the curving line which touches the frame is an arm. An incomplete rendering would be odd, but not unthinkable, since on figure $\mathrm{F}$ an arm was entirely omitted. The legs, in single outline, end in tapering feet with small circles marking the ankles. The warrior's panoply consists of a large, crested helmet, a round shield decorated with a ten-petalled rosette, and a spear held diagonally, point down. In addition, he carries an enigmatic object suspended from a pole. 
The object is defined by successive vertical lines converging at the top to form an angular dome ending in a long loop. A flower is attached to either end of the flat base. Only the right outer side was hatched.

Also facing the prostrate man across the handle, to his left, is a puzzling figure (C), rather top-heavy, with long, thick hair streaming down to the shoulders. Of the large face are preserved the heavy, protruding chin, thick lips, part of the arched eyebrow and the ear. The last is rendered in a manner common on this cup: a $\mathrm{C}$-shaped outline enclosing a bud-like form, rounded on the interior and pointed on the exterior, possibly conventional renderings of helix and tragus respectively. The bent arms, held forward, emerge from the long thick neck and terminate in hands which are awkwardly drawn, with unsure contours and outsized rigid fingers. The farther hand seems to hold a bouquet of flowers to the face. The legs, muscular and rigid, are doubly outlined and terminate in tapering feet which curve like claws. Small circles mark the knees. The peculiar appearance of the figure is increased by the short, tubular dress marked by irregular curved lines suggesting a fleecy fabric. A radiating pattern runs around part of the arm, and a band with $\mathrm{x}$ motifs borders the hem. A pointed headdress, the end of which is missing (perhaps it was a floral ornament), completes the unusual outfit. A lozenge panel stretches from the figure to the handle of the cup.

The four remaining figures (D-G) are not visually linked with the previous group. Of these, two (D and F) are clearly running toward the left, while a third person (E) stands between them looking right, and $\mathrm{G}$ is ahead also moving left. The better preserved figures in this group are markedly distinct from each other and are even drawn with varying skill, almost as if executed by different hands.

Figure D, clad in a cross-hatched top, has an intense and rather humorless expression, which along with his outstretched arms and upturned heel, the only, preserved part of his lower body, suggests strenuous effort. The ear is stylized as in figure $\mathrm{C}$, the eye is set obliquely within the head, the nose is straight and the lips are two narrow curves. The short hair, marked by curving lines, is decorated in the front by a flower. Arms and hands are, as usual, large and rigid.

$\mathrm{F}$, the other running man, is almost completely preserved, which is fortunate since he is also one of the best drawn figures on the cup. He moves rapidly, with one arm bent and held forward, the other forgotten by the artist. Face, body and limbs are, indeed, rendered by sure lines, giving the impression of youthful energy. The facial features are marked by a pronounced nose, smiling lips and a protruding chin. Eye and brow are again oblique, the ear still unrealistically, but now differently, drawn. Carefully detailed is the well coiffured hair, with a large spiral curl at the front, scales at the top and strands tied with a ribbon and running down the back, where they end in upturned curves as if animated by the motion. The clothing consists of a short top with a grid pattern which ends well above the waist and a short, cross-hatched kilt, which leaves the genitals exposed. Like the hoplite, $\mathrm{F}$ is rendered throughout in single outline.

Of $\mathrm{E}$ and $\mathrm{G}$, little is preserved. $\mathrm{E}$ is characterized by a low cranium and short, unmarked hair, heavy chin and ear, as in figure C. The arms appear to be crossed over the chest, and at the level of the waist to the left is a partially preserved circular object with bud-like projections. It is not clear whether this is a background element, or is something attached to or held by the figure. The legs of $\mathrm{G}$ turn left and are outlined twice.

Birds are quite prominent. Two appear behind the hoplite, one pecking the flower attached to the object hanging from his pole, the other perched on a small voluted tree, to judge from the position of its tail, its only preserved part (pl. 61, fig. 1). The resemblance between the barred tails suggests that the two birds may be of the same kind and, to judge from the long neck, bill and legs of the left one, they are probably water fowl. Farther to the right, between F and G, two similar birds, although different in the use of scallops for chest feathers and a dot for the eye, are squatting on either side of two four-petalled rosettes, each marked by an $x$. The bird to their right, shown as if hovering in mid-air, seems to be a larger version of them (pl. 62, fig. 4). Noteworthy in all three cases is that the front leg continues the line of the chest and neck, while the body is almost a separate entity.

Altogether different is the large bird under the handle, identifiable by its tail as a cock (pl. 61, fig. $3)^{4}$ It has a rather long body, broken into sections filled with hatching, scales and chevrons. Its thick, triangular neck terminates in what looks like a bill, which must stand for a head turned right. A similar form loops backward, possibly an attempt

\footnotetext{
${ }^{4}$ I owe this identification to J. Boardman.
} 


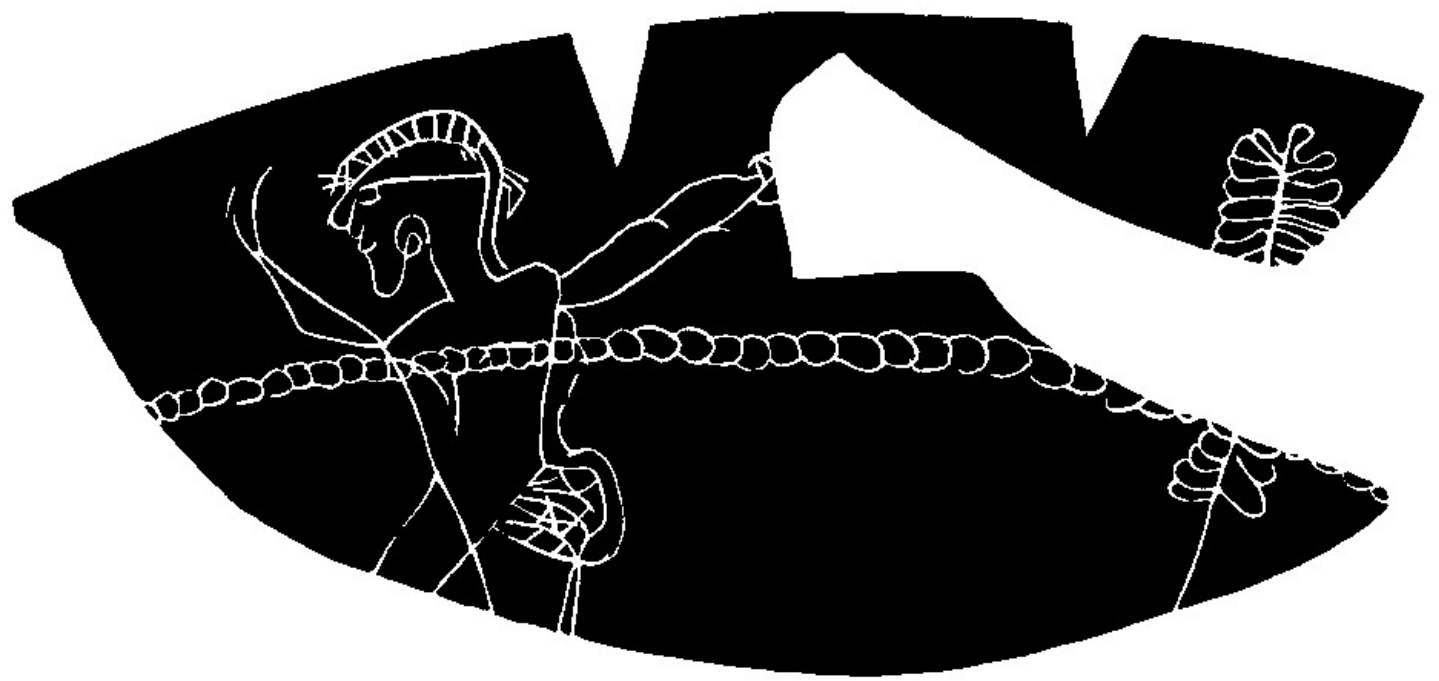

Ill. 3. Kommos, drawing of figurative representation on cup B. (G. Bianco)

to render a crest, but one surely not copied from a real bird. The unrealistic treatment of feathers and head in fact suggests that the artist may have used an earlier model, one of the double-headed birds frequent on Cretan pottery. ${ }^{5}$ Legs and claws are strong and the front part of the bird is outlined twice.

The remaining motifs on the cup are a multi-petalled rosette, only partly preserved above the two antithetical birds (pl. 62, fig. 4), and a lozenge with palmetted corners enclosing a lozenge network ( $\mathrm{pl}$. 61 , fig. 1). A poorly preserved form to the right of the lozenge may be a floral motif (ill. 2).

\section{Cup B (pl. 62, fig. 6 and ill. 3)}

Kommos Inv. no. C2395; Herakleion museum no. n 25788. Max. H.: 0.092 m.; Diam. at rim: 0.12 m.; Preserved: one rim-body fragment, restored from four joining pieces, and a non joining handle. Glaze and technique of decoration as for cup A.

Despite the fad that only a small part of the cup is preserved, it is nevertheless clear that its decoration was not as dense or as ambitious as that of cup A. The drawing is sloppy, as can be seen from the two bands on the lip, a spiral above, a cable below. The man, probably the only one left of a presumably figured main zone, is dad in skimpy, cross-hatched

\footnotetext{
${ }^{5}$ Fortetsa pl. 85, no. 1501; patterns $17 \mathrm{ac}$ and $17 \mathrm{~s}$.
}

shorts; he moves rapidly left with arms spread recklessly in a wildly gesticulating manner. The sketchy treatment, especially of the head, makes this figure almost a caricature. Note the ludicrous outline of the face, with a convoluted curve at the top of the neck, and hatched hair, tied with a string, sitting on rather than growing from the head. Double outlines have been used for the right side of the neck and body. Behind the man is a leafy stem, overlapped, like the man, by a crude cable band which seems to have surrounded the cup.

\section{DISCUSSION AND COMPARATIVE ANALYSIS}

Because of its almost complete preservation, the scene on cup A is the basis for discussing themes. It is significant that the cups were found together, that they show the same unusual decorative technique and, above all, that they seem to repeat at least one basic motif, that of a running man. The interpretation of each cup hinges, therefore, on that of the other. They could even be the products of one man, a craftsman capable of considerable unevenness in his draftsmanship - as witnessed on cup A. Another trait of this artist is that he rendered traditional vase painting motifs sloppily, especially those requiring geometric accuracy, like the lozenge band on the lip of cup A. His heart obviously lay with the widely 
varied, often spirited characters he created. Variations in costume, hairdo and even physiognomy give the impression that we are looking at specific individuals and events, possibly even a narration of a Cretan or Greek myth, although narrative is rare in Cretan vase painting. ${ }^{6}$ On the other hand, it is equally possible that we are dealing with a scene of common activity involving ordinary people.

Composition helps in establishing theme, in determining, for instance, whether the figured zone on cup A contains one or several scenes. That the prostrate man and the two flanking figures form a group is clear. If the entire zone deals with one event, these three individuals probably played a focal role in the story, even though the figure to the left is separated compositionally by the handle. Therefore, their identity and actions should be better defined.

First, to confirm the obvious: the man within the frame is clearly dead, as indicated not only by his posture, but also by the respectful stances of the two flanking figures. Their respect is emphasized by the saluting gesture of the left figure and, possibly, also by the lowering of the spear by the hoplite, for warriors in Cretan art are normally shown with the spear upright, or diagonal with the point up. ${ }^{7}$

The presence of the hoplite, in fact, may suggest that the deceased was also a warrior to be honored. The hoplite stands in full military regalia, but is also unusually equipped with the object suspended from the pole. The bent elements of the latter suggest rods, or, more likely, wickerwork. In fact the shape, apparently cylindrical, with a domed top, suggests a cage - a tempting identification given the presence of so many birds. It is even possible that such a cage might have contained a bird let loose as a symbolic reenactment of the departure of the soul. Although birds appear often in Greek funerary art, however, their exact meaning is not clear; nor is there, to my knowledge, any evidence for such a ritual. ${ }^{8}$ It is more

\footnotetext{
${ }^{6}$ For a summary of themes represented in Cretan art, including pottery, see P. Blome, Die figürliche Bildwelt Kretas in der geometrischen und früharchaischen Periode (Mainz 1982) 65-104.

${ }^{7}$ See n. 31 infra.

${ }^{8} \mathrm{G}$. Ahlberg believes that birds often evoke the idea of death in Geometric pottery: Prothesis and Ekphora in Greek Geometric Art (SIMA 32, Göteborg 1971) 139, 141, 233. See also discussion of birds on the Prinias stelai: Prinias 90-91, 98.

9 Although different in shape, the "basket" can be compared to the "pouch" carried by the Mycenaean warriors on the well known Warrior Vase of the Late Bronze Age: S. Marinatos and M. Hirmer, Crete and Mycenae (London 1960) pl. 233. For the reference in Archilochos, see W.-H. Schuchhardt, "Archäologisches zu Archilochos," Opus Nobile (Festschrift Ulf Jantzen,
}

likely, therefore, that the object is something else, perhaps a basket used as a container for food or clothes, and its inclusion in the scene is intended to convey a sense of urgency, suggesting that the warrior has just arrived or is about to depart, perhaps to the battlefield. A reference to a food container used by soldiers occurs in fact in the work of the seventh century B.C. poet Archilochos. ${ }^{9}$

The identity and even the sex of the figure on the left, in contrast to the hoplite, are obscure. Long hair was apparently worn by both Cretan women and men at that time, but the "dress," much too short for a, woman, ${ }^{10}$ suggests that $\mathrm{C}$ is a man. His may be a special, ceremonial garb, and there is indeed some resemblance between it and that of a figure, surely a man, standing in front of a warrior who presumably represents the deceased, on an engraved stele from Prinias. ${ }^{11}$ The resemblance extends to the gestures of the hands and the holding of a flower. ${ }^{12}$

The meaning of the "frame" is also unclear. Naturally, the position of band and panel and the association of the panel designs with textiles recall canopy and bier in Attic Geometric scenes. There are, however, differences from that scheme, not the least of which is that the corpse lies face down and is not truly placed on a bier. ${ }^{13}$ Moreover, no examples of prothesis are known on pottery from Crete, and the Attic series was rarely copied elsewhere. ${ }^{14}$ It is quite possible that the idea of using this theme arose independently here and that the frame was introduced for pictorial emphasis onto suggest an architectural space. The lozenge panel next to figure $\mathrm{C}$, I believe, stresses the fact that $\mathrm{C}$ is within or immediately next to that space.

Finally, we should note that the cock belongs, strictly speaking, with this group, and to judge from its position next to the corpse which it faces, it is probably more than an ornament. In popular belief in many cultures this bird is associated with apotropaic

Wiesbaden 1969) 153-55. I am indebted to G. Schmidt for this reference.

${ }^{10}$ Daedalic art abounds with examples of female dress. See Blome (supra n. 6) pl. 19, 4.

${ }^{11}$ Prinias pls. 6-7 and discussion on pp. 93-94. A loose tunic is also worn by a clay figurine from Afrati, which has been tentatively identified as a priest: Dädalische Kunst (Mainz 1970) pls. 40-41 and pp. 106-108.

${ }^{12}$ Sprays are held by mourners or placed over the dead in Attic Geometric prothesis scenes: Ahlberg (supra n. 8) 295 and figs. 18, 25, 45. See also Prinias 93-94.

13 For the Attic examples, see Ahlberg (supra n. 8) passim.

${ }^{14}$ For examples outside Attica, see Ahlberg (supra n. 8) 216-19; for the Attic Geometric series see, e.g., J.N. Coldstream, Geometric Greece (New York 1977) 110-13, $117,132$. 
and chthonic functions, and its context here also strongly suggests a funerary connection. ${ }^{15}$

The remaining figures on cup A undoubtedly belong together, the only question being whether both groups are related thematically. Although it cannot be proved, I believe that a single event has been depicted, namely a "lying in state," ordinary or mythical, with special activities held as part of a ritual in honor of the dead. The main activity connected with it seems to be a race, to judge from at least two running figures on cup A (D and E) and apparently one on cup B. The absence of birds on the latter, in fact, lessens the probability that birds were being chased on cup A, as one might otherwise be tempted to think. Birds and trees in A may simply evoke the countryside in which the race took place. This rendering would contrast with the "indoor" setting on the other side of the cup. Although little is known about games at funerals in Crete, it is clear that races were a favored competition. Victory in them was held in high esteem, to judge from the fact that the title dromeus, when granted to a youth, was synonymous with adulthood. ${ }^{16}$

If a race is being held on cup B, the leafy stem behind the runner may have served as a terminus, and it is possible that the chain band, perhaps representing rope, was connected with the game. If so, there may have been a marker on cup A as well, most likely behind the hoplite, in the area with birds and trees. In fact, the fragmentary form preserved next to the floating lozenge (pl. 61, fig. 1) may be another tree, marked with a palmette-like efflorescence at the top and with a vertical lozenge band on the trunk. Such lozenges, alone or as subsidiary patterns on trees, often act as vertical dividers on Cretan vases. ${ }^{17}$ The form has been restored as such in ill. 2, with no claim as to accuracy of shape and details, since only the top remains. It is to be noted that the divider/tree is ap-

\footnotetext{
${ }^{15}$ For the appearance of the cock in the art of Greece and Crete, see D. Levi, "Arkades: Una città cretese all'alba della civiltà ellenica," ASAtene 10-12 (1931) 75, 77; and J. Hastings ed., Encyclopedia of Religion and Ethics 3 (New York 1910) 694-97.

${ }^{16}$ R.F. Willetts, Aristocratic Society in Ancient Crete (London 1955) 7-8, 122-23. For chariot races held in funerals, see representations on a Geometric pot from Kavousi: EHP pl. V.

${ }^{17}$ Cf. Fortetsa pattern 5p, pls. 120, 123, 153, 164.

${ }^{18}$ For seventh century Cretan pottery, see J. Boardman's most useful account in CCO 144-47 and D. Levi's analysis in $E H P$.

19 The Fortetsa cemetery apparently went out of use around 630 B.C., while that at Arkades lingered on to at least the end of the century. See Fortetsa and Levi (supra n. $15)$.
}

propriately located across from the handle. Figure G, ironically now lost, may have been the winner of the race, for he is the closest to that end.

This interpretation of the scenes must remain tentative until we have more specific parallels. Equally unsure is the reason why the cups were brought to the temple, and whether they were simply dedications or offerings made because of the relevance of their theme to the cult. These are questions which can only be dealt with after we gain a better understanding of the temple at Kommos and the nature of the worship.

Individual motifs, on the other hand, such as birds, trees and abstract patterns, can be compared to others in vase painting and provide, therefore, more objective criteria for at least the dating of the cups. In such a comparative analysis, however, one has to bear in mind some problems in dealing with Early Iron Age pottery from Crete, for the lack of uniformity in styles throughout the island, the perseverance of a strong Geometric tradition in later times and the absence of well stratified deposits make details of the history of its development uncertain. ${ }^{18}$ Most of the pottery actually comes from tombs, such as those at Fortetsa near Knossos, and Arkades in central Crete; since the tombs continued in use for a long time, it is difficult to date individual vessels. ${ }^{19}$ Two well stratified domestic deposits found at Knossos $^{20}$ have helped with the dating, which is based essentially-there and elsewhere-on imports of foreign pottery, especially Corinthian. ${ }^{21}$ On the basis of the Knossos deposits, Coldstream has recently lowered the dates proposed by Brock for Fortetsa, by placing the Early Orientalizing period in the first third of the seventh century and by extending Late Orientalizing to about 610 B.C., if not later. ${ }^{22}$

In comparing motifs, Brock's typological study of the Fortetsa material is particularly helpful. ${ }^{23}$ The long-necked birds on cup A, with barred wings and

${ }^{20}$ N. Coldstream, "Knossos 1951-61: Orientalizing and Archaic Pottery from the Town," BSA 68 (1973) 33-63; N. Coldstream and L.H. Sackett, "Knossos: Two Deposits of Orientalizing Pottery," BSA 73 (1978) 45-60. Between them the two deposits span the early seventh century and the range 650-600 B.C., which is the general period to which the Kommos cups should be assigned.

${ }^{21}$ While Athens seems to have been one of the chief sources of influences in the Geometric period, its role was later usurped by Corinth, the Cyclades and Levantine areas. For a discussion of Cretan foreign relations, see $C C O$ 12959.

22 The dating proposed by Coldstream would make Orientalizing in Crete correspond to Late Protocorinthian, Transitional and Early Corinthian, using the dates for Corinthian pottery in T.J. Dunbabin ed., Perachora 2 (Oxford 1962) 6. See Coldstream (supra n. 20) 36. For Brock's chronology, see Fortetsa 213-29.

${ }^{23}$ Fortetsa 168-86. 
often feathered chests, fit well within the Orientalizing period, probably late. They naturally echo earlier birds, but the cock must be a newcomer to the repertoire. ${ }^{24}$ Also new is the fact that birds are not simply space fillers, but are engaged in more active roles, such as pecking at the flower of the basket ${ }^{25}$ or flying at the sudden appearance of man, an action perhaps suggested by the position of the large bird above the ground line in front of one of the runners $(\mathrm{F})$ (pl. 62, fig. 4).

Voluted trees or combinations of floral with abstract designs are also typical of the Orientalizing period. Of these the tree on cup A, visited by birds, is too poorly preserved to allow a sure restoration, ${ }^{26}$ but the almost complete lozenge to its right is a common design on pottery, with an origin traceable to Ionian gold jewelry. ${ }^{27}$ Our type with volutes and palmettes at the corners is characteristic, it seems, of the late phase. ${ }^{28}$ Lozenges and tongues are not very helpful for dating, for they last long and change little. Rosettes are new, however, and guilloches can be instructive, as they are rendered in varying degrees of complexity. Of the guilloches on cup A, the one on the handle seems characteristically Late Orientalizing, ${ }^{29}$ while that over the corpse seems to have an affinity with the floriated guilloches of Middle to Late Corinthian pottery. ${ }^{30}$ The band on cup A is not as elaborate, but if the comparison is valid, we would have here one of the more definite indications of a date in the late seventh century.

Notwithstanding his narrative role on cup A, the hoplite also lends himself to a comparative analysis, for he is common in Cretan art: on limestone stelai, architectural reliefs, armor and, more rarely, pottery.

\footnotetext{
${ }^{24}$ To my knowledge the earliest appearance of a cock on Cretan vases is on a seventh century pithos with stamped decoration, from Phaistos, discussed by Levi (supra n. 15).

${ }^{25}$ The theme of a bird pecking is not entirely new. See an earlier example in EHP pl. 28. 3.

${ }^{26}$ For possible restorations, see Fortetsa patterns 16aj and $16 \mathrm{ak}$.

${ }^{27}$ S. Wide, "Nachleben mykenischer Ornamente," AthMitt 22 (1897) 233-40.

${ }^{28}$ Fortetsa 173, patterns 5bc-5bh, pl. 105, no. 1175, ii. For an example particularly close to the Kommos one: Wide (supra n. 27) pl. VI.

${ }^{29}$ Fortetsa 179 , pattern 1 lab.

${ }^{30}$ D.A. Amyx and P. Lawrence, Corinth 7.2. Archaic Corinthian Pottery and the Anaploga Well (Princeton 1975) 47, pl. 27 no. 153. H. Payne gives this type of motif, admittedly more elaborate than ours, a Middle/Late Corinthian date: Necrocorinthia (Oxford 1931) 156.

${ }^{31}$ For a detailed discussion of warriors in Cretan art and for the particular style of their rendition at Prinias, see Prinias 73-75, 111.
}

Particularly close to ours is the representation of some warriors on the seventh century stelai from Prinias, especially in what has been described by Lembessi as the additive manner of their delineation, ${ }^{31}$ and the way the shield, often decorated with rosettes, entirely hides the torso. ${ }^{32}$ The helmet with lofty crest curving forward and no cheek pieces seems to correspond to type B in Snodgrass' typology of Greek armor. ${ }^{33}$ The spear is harder to classify: the blade is shaped like a short, broad leaf, with lines curving outward at its base, more like a barbed arrowhead. ${ }^{34}$

If these motifs point to the Orientalizing period, it is particularly the impressive and essentially unparalleled emphasis on lifelike rendition of human figures and on elaborate scenes which suggests that we have reached a mature stage in this rich artistic era. In the profusion of disparate motifs, the strange co-existence of man, bird and filling ornament, in the exuberant and often humorous portrayal of people, the decoration approximates the mood and spirit of Protoattic vase painting, but figures here (at least on cup A) are more supplely rounded and-although merely incised - they can be quite detailed.

With one exception, human representations in this technique are unknown in Cretan pottery. The exception is an unpublished fragment of an oinochoe, consisting of two joined sherds, found in 1955 on the east slope of the akropolis of Gortyn, next to a retaining wall below the big altar, but, unfortunately, from a mixed stratum (pl. 62, fig. 7). ${ }^{35}$ On it appears a youth turning left and holding out with one hand a footed, two-handled vase and, with the other, what I believe to be a quadruped, possibly a goat, by the rear legs (ill. 4). Both of the man's arms are outstretched,

\footnotetext{
${ }^{32}$ For examples of warriors with similar shields, see: Prinias pls. 12 b, 13 b; H. Hoffmann, Early Cretan Armorers (Mainz 1972) 6, fig. 6; B.S. Ridgway, The Archaic Style in Greek Sculpture (Princeton 1977) pl. 51.

${ }^{33}$ A.M. Snodgrass, Early Greek Armour and Weapons (Edinburgh 1964) 16.

${ }^{34}$ Cf. A.M. Snodgrass, Arms and Armour of the Greeks (London 1967) fig. 35.

${ }^{35}$ I would like here to thank Dr. A. Lembessi and my husband, who, independently, first called my attention to the Gortyn piece $(0.125$ x 0.065 m.; Herakleion Mus. no. 55/4901) as a parallel for the incised technique. I am also grateful to Professors G. Rizza and A. Di Vita for permission to discuss it and for the photograph (here pl. 62, fig. 7). According to information provided by the Italian School of Archaeology in Athens, the fragment was found in an upper level of fill in front of the so-called "scacchiera" wall (see G. Rizza and V. Santa Maria Scrinari, Il santuario sull'acropoli di Gortina 1 [Rome 1968], where the level, I believe, is the one numbered 4, in the section on pl. G; for a discussion of this level, see $\mathrm{p}$. 125).
} 


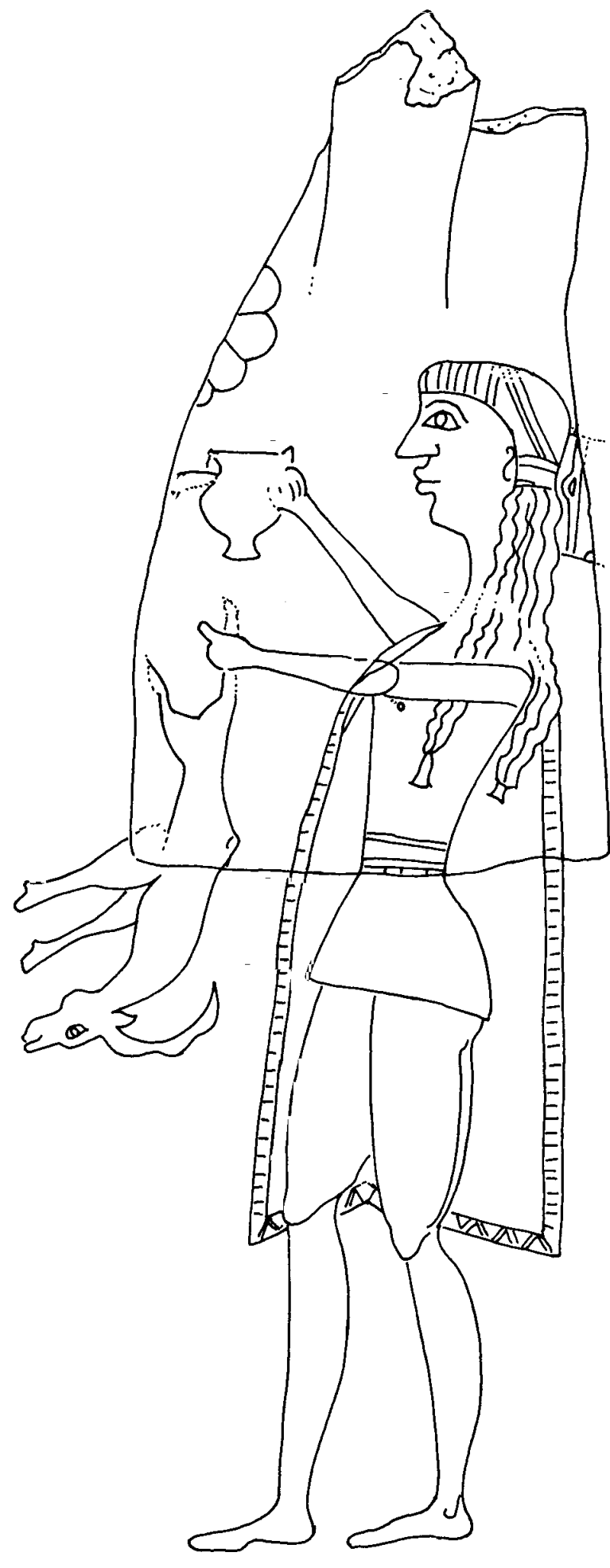

Ill. 4. Gortyn, tracing and partial restoration of incised scene on oinochoe fragment. (M.C. Shaw) as if the items were being offered. He wears a cape with barred borders over a bare torso, to judge by the indication of the nipple. A belt with lines below suggests a kilt or shorts. His long hair, marked by striations at the front, is tied at the back. Two wavy strands, also tied at the bottom, fall on either side of his arm. The face has a pronounced nose, fleshy, protruding lips, a large, almond-shaped eye and a rounded chin. The cranium is rather low, the arms are thin and rigid, the elbow marked by a circle and the fingers fairly well drawn. Preserved details of the background are a band behind the man's head and part of a rosette to the left of the handle.

The technique of decoration on this fragment incision on a black-glazed surface before the firing of the pot - is exactly that of the Kommos cups, although the design may have been executed by a different hand. The similarities make it certain, however, that the vases from the two sites are contemporary and that neither is an odd, isolated experiment. There are, in fact, other examples known of this technique of decoration, but their motifs are very simple: abstractions, florals and birds ${ }^{36}$ Related techniques of decoration are incision combined with silhouette and, sometimes, added colors, comparable to that used on Protocorinthian pottery, ${ }^{37}$ and incision, often used along with relief, found on what has been described as "Cretan bucchero," a ware not common in the seventh century. ${ }^{38}$ Bucchero has also been found in Aiolia, especially Lesbos, in Naukratis and, of course, in Etruria, where a fine variety, known as "bucchero sottile," often with figurative incised decoration, is characteristic of the last quarter of the century. ${ }^{39}$ One example of a bucchero jug from Fortetsa is particularly interesting, for its decoration is done entirely by incision and its visual effect is close to that of our cups, even though the firing technique and the fabric are not the

${ }^{36}$ From the akropolis of Gortyn come two fragmentary cups; D. Levi, "Gli scavi del 1954 sull'acropoli di Gortina," ASAtene 17-18 (1957) 233, fig, 16. For the Knossos example, decorated with tongues, see Coldstream (supra n. 20) 51,60 and pl. 11, 7a.

37 There is, however, the rare case where motifs are rendered exclusively by incised outline on a dark ground, even in Corinthian pottery, as on a Protocorinthian to Transitional olpe imported to Knossos (JHS-AR 1978-1979, 53, fig. 35).

${ }^{38}$ For a discussion of bucchero in Crete, see Levi (supra n. 15) 532-33.

${ }^{39}$ For the origin of the ware and its distribution, see J. Boardman, The Greeks Overseas ${ }^{2}$ (London 1980) 32-33, 47-48, 124, 208, 217, 249. For the development of Etruscan bucchero, see a recent discussion in O. Brendel, Etruscan Art (Middlesex 1978) 47, 78-80. 
same. ${ }^{40}$ The similarity, moreover, is enhanced by the depiction on the Fortetsa vase of a plant close to the one on cup B, both in the way it stands apart compositionally and in its lack of stylization.

Like Etruscan bucchero ware, which has been thought to imitate metal vases, certain aspects of the cups from Kommos point in the same direction. Thus, their shape, although not uncommon, has been thought to originate in metal prototypes. ${ }^{41}$ Most significant from this point of view, however, is the use of double outlines, tried also on the cups, albeit halfheartedly — a device more normally used in incised

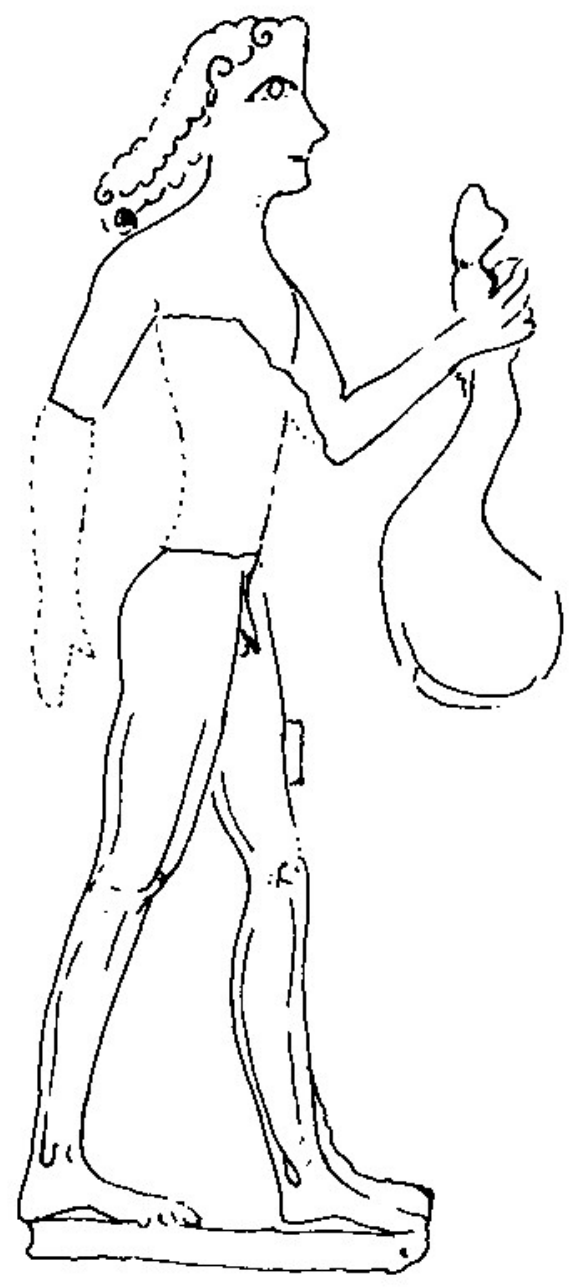

III. 5. Syme, tracing and partial restoration of cut-out bronze plaque. (M.C. Shaw, after Prinias pl. 52.a)

40 Fortetsa pls. 100, 160, no. 1247, described as "bucchero."

${ }^{41}$ Fortetsa 167 . For a strikingly metallic-looking profile in Cretan bucchero, see Levi (supra n. 36) 230, fig. 23a.

${ }^{42}$ Lembessi comments on how double contours outlining figures on the stelai from Prinias seen to emulate decorative

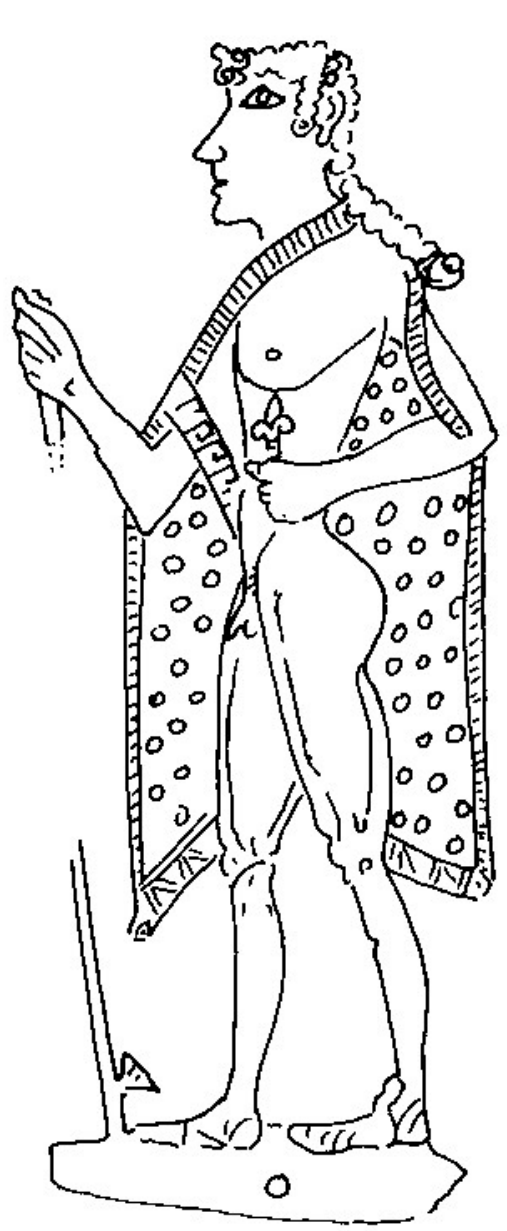

Ill. 6. Syme, tracing of cut-out bronze plaque. (M.C. Shaw, after Prinias pl. 52.b)

and repoussé decoration of metal objects, apparently to create an impression of depth in low relief. ${ }^{42}$ Two classes of objects to which we can turn for sources of inspiration for the designs are bronze armor and bronze cut-out plaques, both with incised and repoussé decoration.

Of the armor, which is found at several sites in Crete, the rich collection from Arkades, recently dated by Hoffmann to the late seventh century, seems to provide the best parallels. ${ }^{43}$ Particularly close to the men on cup A are winged heroes grasping two intertwined snakes depicted on a helmet, not only because of the similarities in general physiognomy, but also in the fullness of the bodies, the lively gestures and the sense

techniques used in metalwork: Prinias 39-40.

${ }^{43}$ Hoffmann (supra n. 32) 42-43, bases his dating on analogies with Transitional Corinthian, Corinthian and Attic ceramic motifs. 
of motion. ${ }^{44}$ The way the hair strands of the winged heroes have been tied at the bottom is, moreover, paralleled in the man from Gortyn (pl. 62, fig. 7).

The basic theme on the bronze plaques ${ }^{45}$ is that of hunters carrying game. The recent discovery of vast numbers of plaques at the sanctuary at Syme makes clear their religious function and suggests that the animals depicted on them probably represented those used as sacrificial offerings. The theme of offering an animal is itself instructive for our purposes, for I believe it is also depicted on the Gortyn vase (pl. 62, fig. 7), which thus forms a crucial link between the Kommos cups and the plaques. The youth on that fragment is holding out an animal, probably a goat, by the rear legs. Parallels in the plaques for this action (ill. 5), as well as the costume (ill. 6), allow a tentative restoration of the Gortyn man (ill. 4). There is also a definite resemblance between some figures on cup A, particularly F, and the man on a plaque in the Louvre, ${ }^{46}$ especially in the flamboyant coiffure, the low cranium, the rigid hand and the unrealistic

${ }^{44}$ Hoffmann (supra n. 32) pls. 1-5.

45 The number of plaques known from a few sites in Crete and from a few examples in the Louvre and in Copenhagen has been dramatically increased by recent discoveries at Syme. For preliminary reports on the Syme plaques, see A. Lembessi in: Praktika 1972, 193-203; 1973, 188-99; 1974, 222-27; 1975, 322-29; 1976, 400-407; 1977, 403-18; JHS-AR 1973, 30-31; AAA 6 (1973) 104-14 and Prinias 108-10. For illustrations and discussions of the treatment of the ear. If the date suggested for the Louvre and other comparable plaques by Boardman and more recently by Hoffmann is correct, both the Kommos cups and the Gortyn oinochoe may also belong to the third quarter of the seventh century, if not later. ${ }^{47}$ If the Gortyn vase seems more closely related to the plaques than the cups, it is mainly because of the thematic connection. There is no doubt, however, that all three sets of objects are interrelated.

The ambitious and lifelike depictions of men from Kommos and Gortyn have no precedents in ceramics, nor, to my knowledge, does this style of vase painting develop further. At the moment, the three examples seem to represent a short-lived and attractive experiment receiving its inspiration from a different medium. To judge by the findspots of the few examples known, the style finds its home in south central Crete.

\section{SCARBOROUGH COLLEGE}

UNIVERSITY OF TORONTO

TORONTO, CANADA

other plaques, see $C C O$ 46-48; Hoffmann (supra n. 32) pls. 48-49.

${ }^{46}$ Prinias pl. $51 \mathrm{~b}$.

${ }^{47}$ For a discussion of dates of the pre-Syme plaques, including the one in the Louvre, see CCO 47-48, 141; Hoffmann (supra n. 32) 32-33, 46; Dädalische Kunst (supra n. 11) 41-43. 
Fig. 1. Kommos, cup A after restoration: side with prostrate man and hoplite. (Photo T. Dabney)

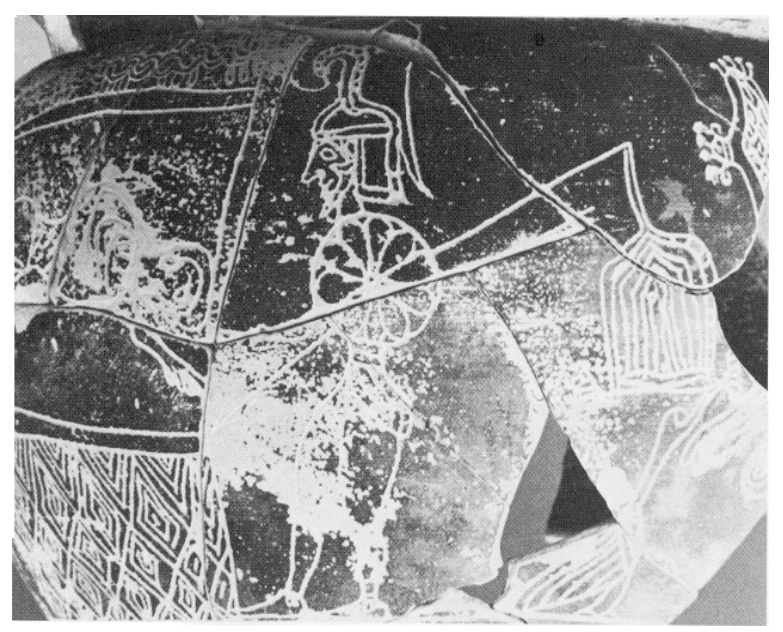

Fig. 3. Kommos, detail of cup A before restoration. (Photo R. K. Vincent, jr.)
SHAW PLATE 61

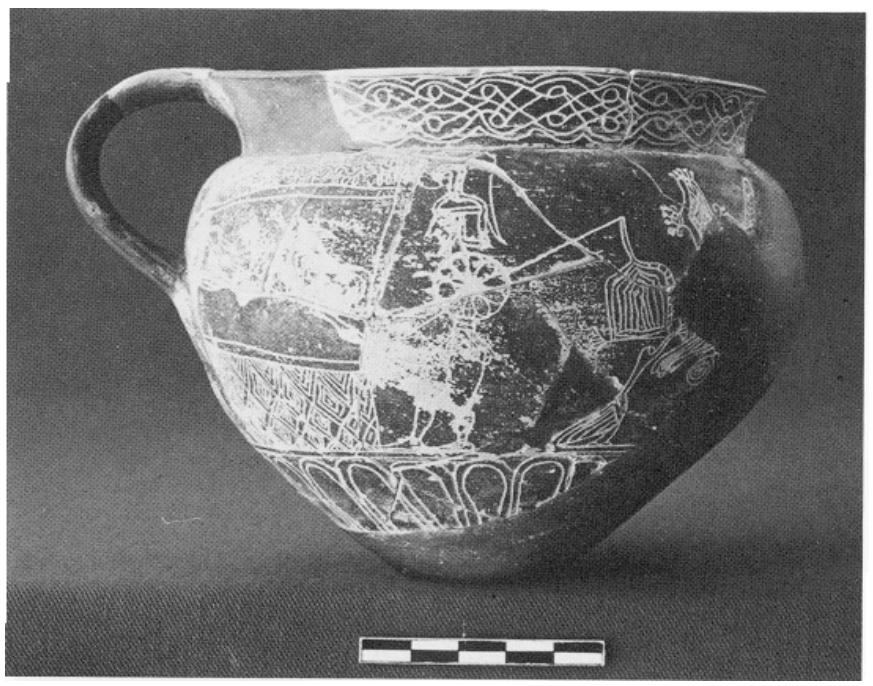

Fig. 2. Kommos, cup A: detail of the hoplite. (Photo T. Dabney)

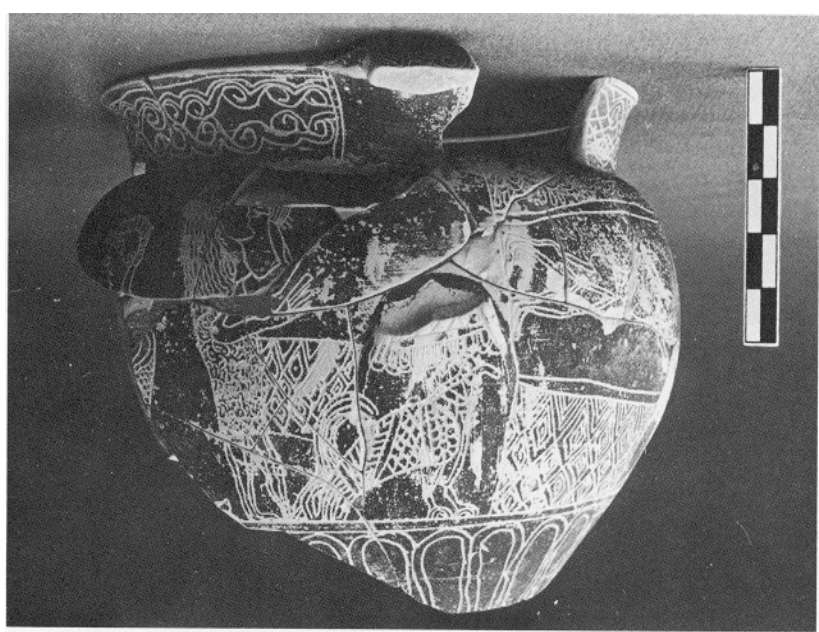




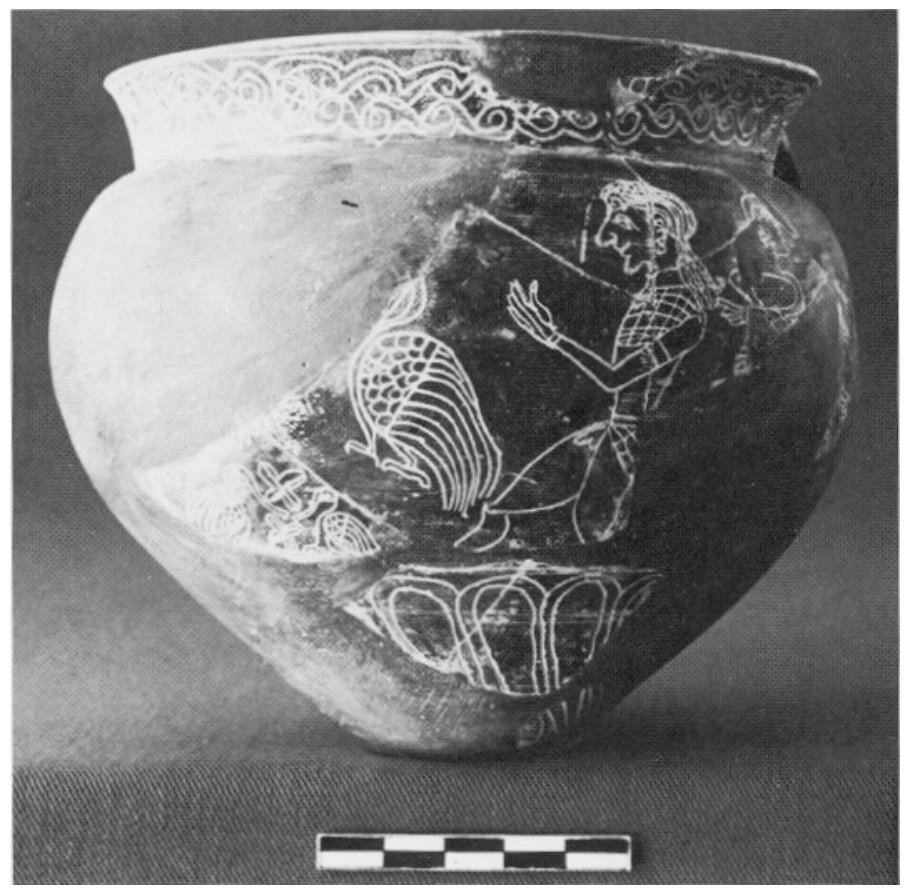

Fig. 4. Kommos, cup A: "runner" and bird. (Photo T. Dabney)

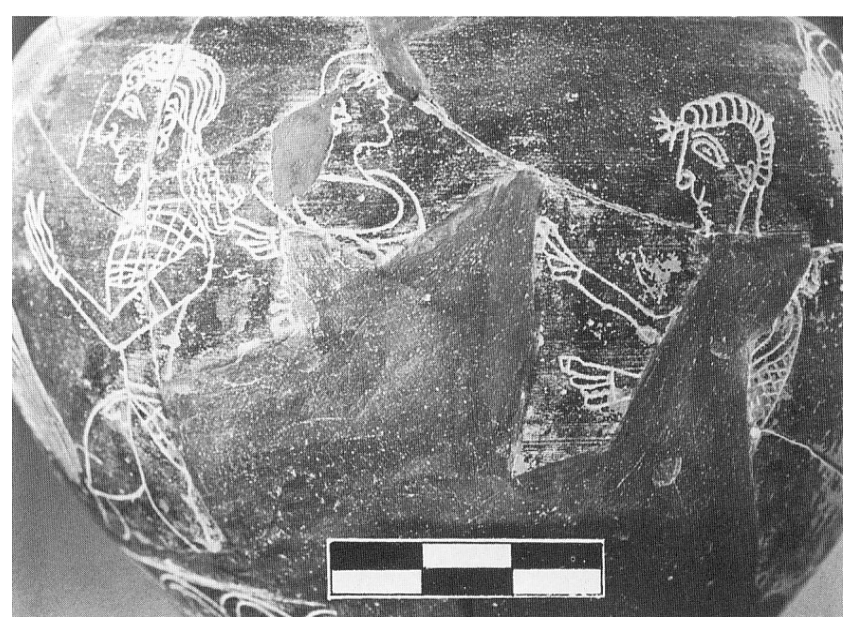

Fig. 5. Kommos, cup A: two "runners" and another figure. (Photo T. Dabney)

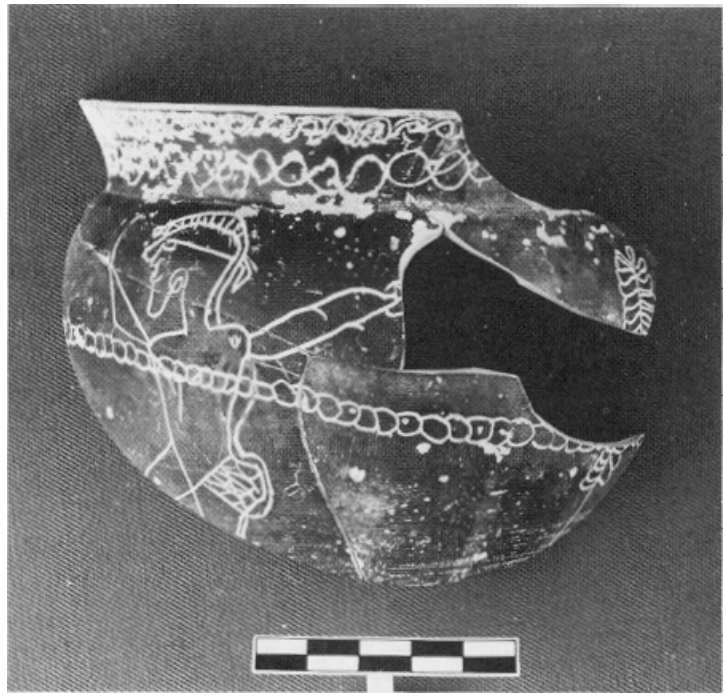

Fig. 6. Kommos, cup B. (Photo T. Dabney)

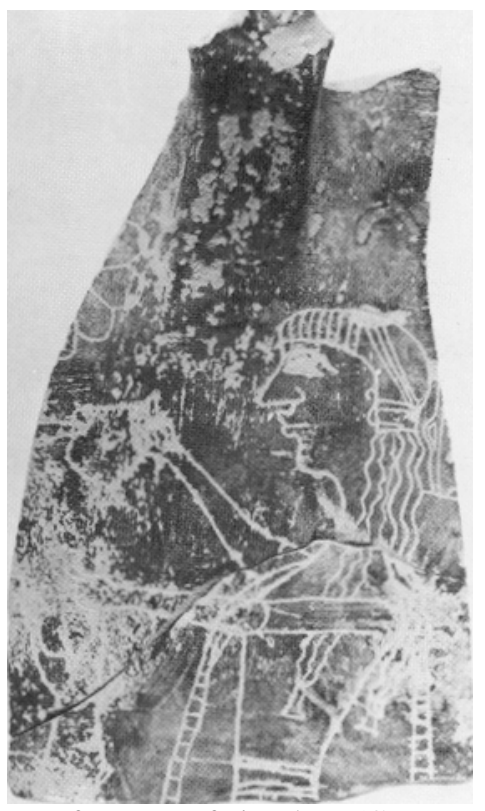

Fig. 7. Gortyn, fragment of oinochoe. (Courtesy Italian School of Archaeology, Athens) 